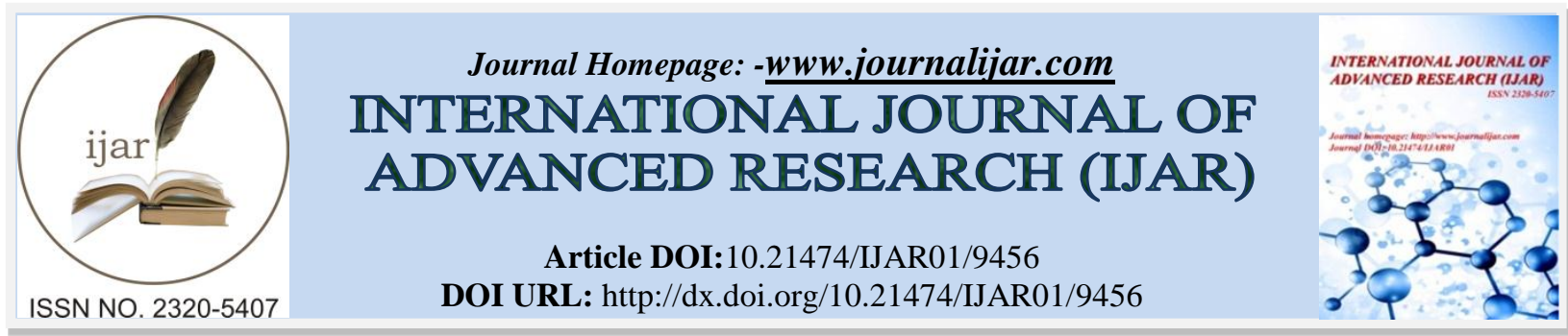

RESEARCH ARTICLE

\title{
REFLECTION OF CHANGING TRIBAL LIFE AND CULTURE OF ARUNACHAL PRADESH IN THE SHORT STORIES OF YESHE DORJEE THONGCHI.
}

Bhagyashree Gogoi.

Junior Research Fellow,Dept.of Assamese,Dibrugarh University, Assam, India.

\section{Manuscript Info}

Manuscript History

Received: 24 May 2019

Final Accepted: 26 June 2019

Published: July 2019

Key words:-

Arunachal Pradesh, Tribal Life and Culture, Short Story, Yeshe Dorjee Thongchi.

\section{Abstract}

Arunachal Pradesh is an amazing state of North-East India. For this reason the place makes people curious to study the traditional element like Traditional custom, belief, folk literature, folklore etc.Yeshe Dorjee Thongchi is an Assamese writer, who tries to reflect diverse life of Arunachal Pradesh .The various tribes of the state of Arunachal are Adi, Monpa, Sherdukpen, Nyishi, Apatani, Mishimi etc.Through his stories he shows how changes are there life of the tribal people, how originality has been influenced by the new social system. This paper tries to explain how Yeshe Dorjee Thongchi reflects the changing life and culture of Arunachal Pradesh in his short stories.

Copy Right, IJAR, 2019,. All rights reserved.

\section{Introduction:-}

Arunachal Pradesh is one of the amazing place of the North-eastern region. Different tribal groups having their distinctive language, culture, traditions and custom live here. But it has been noticed that there is a great change in the traditional life of these tribal groups. . There may be several factors responsible for the changing scenario in the lifestyle of these people. One among these are the impact of the modern life style on the tribal people. People are more fascinated towards the modern means of life and have left their own customs, culture behind.

There are several writers in Assamese writer who have reflected these changes in their writings.One among them is Yeshe Dorjee thongchi. Who in his writings show the changing culture of Arunachalle.Though Yeshe has written novels but in my paper an attempt has been made to highlight the changes in the life and culture of the tribal society of Arunachal Pradesh in his short stories.

\section{Objectives}

The chief objective of the paper is to examine the changes that have come across in the Arunachalle society:

To examine the changes in the culture and tradition of the Arunachalee tribes as reflected in the short stories of Yeshe Dorjee Thongchi

\section{Methodology:-}

Critical analysis method is used in the paper.

Reflection of tribal life in the short stories of Yeshe Dorjee Thongchi

Literature has deep relation with the society and culture.Assamese literature also beautifully presented tribal thought, custom etc.Yeshe Dorjee Thongchi is a one of the writer, who take tribal life of Arunachal Pradesh as a plot 
of his creation. He explains the thought of tribal people, changing traditional customs, for the new accommodation how depression and intrigued coming in hill people's life. For the study, three collection of short stories-'Papor pukhuri' (Pond of sin), 'Bah fulor Gundho' (Fragrances of Bamboo Flower), 'Ainyo akhon pratujugita' (Another competition) has been chosen.

\section{Traditional tribal life of Arunachal Pradesh}

Tribal life means tribal society and their culture. Yeshe Dorjee Thongchi gives his short stories flavor of the traditional life of Arunachal Pradesh.

\section{status of Women}

Yeshe Dorjee Thongchi in his short stories reflects the status of women in different tribes in the state of Arunachal Pradesh. In the short story 'Pharr sha' (shadow of Mountain) the writer mention a Laju Nocte girl, where she has to prove her motherhood before going to her in-laws house. The girl is not accepted unless she gives birth to a child from another man and a very cruel system of killing the baby is practiced among the Noctes.In the short story the girl Kamthuk is shown to be protesting against the traditions where she has been forced to sleep with some other man and killed the baby child.

In the short story 'Atithi debo vobo'( Guest is like God), the writer throws light into the Apatani society and their treatment towards women. The Apatani society is sees to always consider the daughter-in-laws from a different caste with a different eye. Apatanai society can't give respect. Even not allowed to participate her in any social activities. 'Antohin Akha' (Restless hope),'Kono Khed nai' (No any regret) type short story proves the child marriage system of Tribal society. Groom buys the girl from her parents.

\section{Food habit of Arunachal Pradesh:}

The tribes have a special food habit. Environment and ecological system make food habit different. Many years ago, it was the ritual of among the tribes of Arunachal offer guest Laopani (traditional homemade rice wine).Now educated people offer tea instead of laopani.Various tribal people eat fish, meat ect.But in the story 'Mangkho' (Meat)Thongchi explain that the Monpas prefer to be vegetarian as they are believer of Buddhisim.Because in Buddhisim killing of animal is considered to be a sin.

\section{Religion}

Some of the tribes of Arunachal Pradesh belief in Buddha religion. Some tribes try to keep their ancient religion like animism;Donyee-polo.

\section{Folk belief of reflected in Yeshe Dorjee Thongchi's short story}

Yeshe Dorjee Thongchi's another short story 'Bah Fulor Gundho' (Fragrance of Bamboo Flower) draw picture of folk belief. There is a folk belief among the tribal people that blooming of bamboo flower is a bad 'omen'. Blooming of this is believed to show the increase of the fertility rate of the rats. This leads to the destruction of the crops and the end is food crisis. There was a time when a person suffering from plague disease was burnt alive. In 'Papor pukhuri' (Pond of Sin) the writer has shown how the tribal people believe that the Plague disease is a result of some sins done in the previous life. In the short story 'Aru Ajon mohapurush' (And a great man) the character of Dorjee Wangdi also reflects the folk belief still practiced among the tribal society. When Dorjee Wangdi's wife Pemleta was raped and killed, he want to the court for proper judgement.According to the court's judgments the criminals were be hanged. But the husband insisted the court that it should not be done his wife soul will not be in peace were after her death. This kind of beliefs was prevalent in the society of Arunachal Pradesh.

\section{Changing scene of Tribal Life in Arunachal Pradesh.}

Many way of political, social, religious, economically changes coming in the Tribal life of Arunachal Pradesh. Educated people have growing up and they tried to avoid old rituals. Corruption, fake evidence, material culture created problem in tribal society.

\section{Political changes}

Arunachal Pradesh before known as NEFA (North East Frontier Agency). That time there is nothing any proper road communication. The Political Interpeter, which is called 'Kataki', was only medium to communicate with the tribal people.NEFA Government all time takes the help of 'Kataki' to solve the problem. But when Arunachal Pradesh was declared a fully fledged state, the service of Kataki was not necessary. The new administration did not want a 
political interpreter. They also lost their earlier bonus from Government. This unexpected truth is reflected in the short story 'Sewa Poroskar' (Service Prize).The character of the story Tajang Kataki is symbol of change occurred in the political scenario of Arunachal Pradesh.

North -East India's tribal people are advanced than another tribal people of India in economic, social, and political side. But government scheme is not properly utilized for common people. In the story 'Aboidho Awashi'((Unexpected staying) Thongchi tries to throw light into the activities done by the government which are of no proper use for the benefit of the tribal people of that area.'Aohaliya'is a village of the Misimi tribes. A tourist lodge was built in that area and the idea behind building the lodge was that the people of that local area would also benefited by that. The problem of unemployment would be solved to some extent if the local youths would be given a chance to extend their help and support in that lodge. The unemployed Youths tried their best to appoint themselves in the vacant posts of the lodge. But all efforts of these people became null and void.Inspite of their going up and closer to the government for employment was useless. Gradually it was noticed that the lodge was used for several other purposes. An old man named Akini Mepo who was homeless also started staying there. This was also brought to the notice of the government. The govt. immediately promised the man to give a home under the 'Indira Avakh Yojna Scheme' and asked him to leave the place. As promised he left the place but the promise by the government remained only as a promise and practically no home was given to that homeless man. Through the story the writer shows the negligence of the government and the fakeness of the government officials.

\section{Changes in the customs.}

In the story 'Ronga torar abahan' (welcoming red star), the writer shows the change that has come upon the tribes of Arunachal Pradesh. The Christian Missionaries are spreading the Christian religion and influencing the local people of that area. The story- teller in this story says:

"If the Arunachally people transform their religion at the present rate them there will be a day when their 'DonyiPolo' would completely vanish. No single person would remain as a believer of their Donyi-Polo in the near future."In the short story storyteller Miken Riba's family was conservative of their own religion-customs and culture and they keep distance to do such type work which is against their religion. But the last scene of the short story shows that Miken Riba's mother is also not away from the invitation of red star. According to her mother, there would not be a single person left in the village of the Donyi-Polo faith. When she noticed that everyone avoided their earlier faith and was influenced by the Christian faith and belief. The mother felt lonely. At last the mother also started believing in the Christian faith with the call of the red star. The Sherdukpen priests' mental situation is narrated in the story 'pujari'(Priest).His mental agony after losing his earlier glory and importance in the society as a 'Priest' is the here. Even he was afraid of his grandson 'Wanzha's signs of becoming a priest. The priest tried to put that thought of becoming a priest from the mind of the grandson. Otherwise in the near future he would also have suffered from the same mental condition as he is undergoing now. So the grandfather insisted or sending his grandson to send him to a Buddhist school and become a Lama instead of a priest. The grandfather realizes the uselessness of a priest in the upcoming modern world. Yeshe Dorjee thongchis 'Duchinr Dina Aimonepohokol'(Rituals believer in the Day of Duchin)short story shows disgusting situations in Religion place. It is going to be like fashion. Devotional thinking is outside.

Crisis arises to keep their own religion of Arunachal Pradesh because Spread of other religion, changing mentality of newly educated people.

\section{Economic Changes}

Basically tribal people of Arunachal Pradesh depend on Jhum-cultivation, hunting, fishing etc. But new time has changed their economic life. Yeshe Dorjee Thonchi,economic changes in the life of the tribes is reflected 'Hilot goja benguniar hoite' ( Born in stone with violate). The labour who came for the road construction in hill village Jigaon. Wooden business also started coming up. The economic condition of the people growing up. But all of a sudden the order of the supreme court of protecting the forest was paused. The order brought a sudden change into the economic life of the tribes. The people who were working outside came back to their own village. Even the students had to come back to their own villages. Thus there was a great change in the economic scenario of Arunachal Pradesh. 


\section{New social system change tribal people life}

Tribal life of Arunachal Pradesh started developing because of the advantage of education ,economic, transportation etc .Proper education inspired the young generation avoid to old rituals .Changes came to their life style also.Apatani is one of the tribe of Arunachal.Apatani women doing Tatto,its called 'Tipe'.Tipe is their own beautiful mark. But this is not done now days. The new generations do not have 'Tattoos' which the old people did. The educated young man's are ashamed of doing physical labor. These are the changes observed by the writer in the short story 'Jatra'(Travel).

\section{Conclusion:-}

In the short story of Yeshe Dorjee thongchi these reflects the changes that has come upon the tribal society of Arunachal pradesh.Thus it has been found in the study that the short stories of Thongchi, the writer has shown how the various tribes in Arunachal Pradesh are undergoing changes in their social, political and economic life due to the upcoming changing trends.

\section{Citation:-}

1. Thongchi, D.Y.(2000).Papor Pukhuri, journal Emporium.

2. (2005).Bah fulor Gundho.Banalata.

3. (2009).Aino akhon pratijugita.Banalata.

4. Bose, M.L. (1997).History of Arunachal Pradesh. Concept publishing company.

5. Dutta, J. (2012).Ethnicity in the fiction of Lummer Dai and Yeshe Dorjee Thongchi a new historicist approach, Adhyayan publishers \& Distributors. 